\title{
Mutabilidad de los contratos de la administración en el Derecho uruguayo
}

\author{
Mutability of management contracts in Uruguayan law
}

\author{
JUAN PABLO CAJARVILLE PELUFFO*
}

Resumen: El artículo resalta la importancia práctica y teórica de la contratación administrativa. Por ello, explica el consenso doctrinal que justifica el carácter vinculante de los contratos de las entidades estatales para, posteriormente, desarrollar los modos, los motivos, los fines y los límites de la modificación de los contratos. Finalmente, sobre la base de la jurisprudencia uruguaya, nos explica la recepción de los tribunales respecto de la (in)mutabilidad de los contratos administrativos.

Palabras clave: Contratación administrativa - modificación contractual mutabilidad de los contratos - educación económico-financiera

Abstract: The article highlights the practical and theoretical importance of administrative contracts. Thus, explains the doctrinal consensus which justifies the binding nature of contracts of state agencies to develop ways, motives, purposes, and limits of contract modifications. Finally, based on the Uruguayan courts, describes the reception of the courts concerning the (im) mutability of contracts.

Key words: Administrative recruitment - contract modification - mutability of contracts - economic and financial education

CONTENIDO: PRESENTACIÓN.-I. EFICACIA VINCULANTE DE LOS CONTRATOS

DE LAS ENTIDADES ESTATALES.- II. LA MUTABILIDAD DE LOS CONTRATOS

DE LA ADMINISTRACIÓN.- III. LOS MODOS DE LA MODIFICACIÓN CONTRACTUAL.- IV. LOS MOTIVOS DE LA MODIFICACIÓN CONTRACTUAL.V. LOS FINES DEBIDOS DE LA MODIFICACIÓN CONTRACTUAL.- VI. LOS LÍMITES DE LA MODIFICACIÓN DE LOS CONTRATOS.- VII. MODIFICACIONES IMPUESTAS POR EL DERECHO.-VIII.LAS "TEORÍAS"SOBRE EL MANTENIMIENTO DE LA ECUACIÓN ECONÓMICO-FINANCIERA DE LOS CONTRATOS DE LA ADMINISTRACIÓN.-IX. ADMISIÓN DE LA MUTABILIDAD DE LOS CONTRATOS DE LA ADMINISTRACIÓN POR EL TRIBUNAL DE CUENTAS DE LA REPÚBLICA.X. CONCLUSIÓN.

* Es ex catedrático y ex director del Instituto de Derecho Administrativo de la Facultad de Derecho de la Universidad de la República Oriental del Uruguay. 


\section{PRESENTACIÓN}

La contratación de la administración reviste una enorme importancia a la vez práctica y teórica, particularmente en Uruguay, porque aquí la riquísima casuística que ofrece la realidad debe resolverse por oferentes y contratantes, administradores y jueces, provistos de muy pocas normas legales ${ }^{1}$, relativas sobre todo a cuestiones de procedimiento, y, por ende, con necesaria y enriquecedora aplicación de conceptos y principios de Derecho - "reglas de Derecho" explícitamente integrantes de nuestro ordenamiento-, unos aplicables a toda actuación de la administración y otros específicos de su contratación.

Las siguientes consideraciones no emanan de la fría reflexión del laboratorio: provienen casi todas directamente de esa realidad práctica y son el fundamento abstracto — si se quiere, la premisa mayor — del análisis de casos concretos ocurridos realmente.

\section{EFICACIA VINCULANTE DE LOS CONTRATOS DE LAS ENTIDADES ESTATALES}

No requiere mayor fundamentación, porque es casi intuitiva, la afirmación de que los contratos vinculan a las partes, les confieren derechos y les imponen obligaciones ${ }^{2}$. La convicción social predominante en nuestro ámbito cultural, que lleva a que esa idea se perciba hoy como una verdad evidente que se alcanza intuitivamente, conduce a considerarla un "principio general de Derecho", que desde otro punto de vista podría verse como derivado del "Derecho natural" guayo dispone que "los contratos - convenciones por las cuales una parte se obliga para con la otra o ambas partes se obligan recíprocamente a una prestación cualquiera - legalmente celebrados forman una regla a la cual deben someterse las partes como a la ley misma" (artículos 1247 y 1291). Por su parte, el Código de Comercio prevé que "Las convenciones legalmente celebradas son ley para los contrayentes y para sus herederos" (artículo 209).

1 Las normas legales sobre contratación de la administración vigentes en Uruguay, contenidas formalmente en leyes diversas, han sido ordenadas por decreto del Poder Ejecutivo 194-997 del 10 de junio de 1997, denominado "Texto ordenado de contabilidad y administración financiera" (en lo sucesivo tocaf). Aunque contenidas en un reglamento, sus disposiciones, que recogen a la letra las legales, tienen por ello valor y fuerza de ley formal.

2 Sobre el origen filosófico e histórico de la idea del contrato como acuerdo de voluntades que crea efectos jurídicos, puede verse Soto Kloss, Eduardo. "La contratación administrativa: un retorno a las fuentes clásicas del contrato". Revista Uruguaya de Estudios Administrativos, № 1, Montevideo, 1979, pp. 43-51.

3 El Derecho positivo uruguayo incorpora expresamente a "todo principio de derecho" como reglas de Derecho integrantes de su ordenamiento, con valor y fuerza constitucional, aquellos que se refieren a derechos, deberes y garantías "que son inherentes a la personalidad humana o se derivan de la forma republicana de gobierno" (Constitución, artículo 72) y con valor y fuerza de ley los demás (Constitución, artículo 332; Código Civil, artículo 16; decreto ley 15.524 del 9 de enero de 1984, "Orgánico del Tribunal de lo Contencioso Administrativo", artículo 23 apartado a, repitiendo la solución de la ley 13.318 del 28 de diciembre de 1964, artículo 345).

4 Cajarville Peluffo, Juan Pablo. "Reflexiones sobre los principios generales de derecho en la Constitución uruguaya". En Estudios jurídicos en memoria de Alberto Ramón Real. Montevideo: 1996, pp. 159-166. 
Un importante sector doctrinario negó la existencia de verdaderos contratos entre los actos jurídicos en cuyo perfeccionamiento participe la voluntad estatal ${ }^{5}$. Superando esos cuestionamientos doctrinales, nuestro Derecho positivo admite desde el nivel constitucional que las entidades estatales celebran contratos ${ }^{6}$ y, consagrada esa solución, debe afirmarse que también para ellas los contratos tienen eficacia vinculante? Este principio general de Derecho se recoge a texto expreso al incluirse las normas contractuales entre las "reglas de Derecho" que vinculan a la administración y cuya violación es causa de invalidez y consiguiente anulabilidad de los actos que dicte ${ }^{8}$.

Por eso, ha dicho con acierto el Tribunal de lo Contencioso Administrativo con respecto a los contratos de la administración:

Devienen perfectamente aplicables al caso, los principios generales de la contratación manejados en la esfera privada, tales como el de que el contrato 'es la ley de las partes' y el de que los contratos no sólo deben celebrarse, sino también cumplirse de buena fe. Tales principios, en el terreno de la Administración Pública, sólo ceden ante un texto claro, expreso, y desde luego aplicable al caso $[\ldots]^{9}$.

El Tribunal de Cuentas de la República ${ }^{10}$ adoptó hace pocos años una posición singularmente rígida sobre la eficacia vinculante de los

5 En nuestra doctrina, esta tendencia estuvo representada por Aparicio Méndez, quien sostuvo que el contrato como instituto "lo creó el derecho privado y no tiene sentido aplicarlo fuera de él", y agregó: "Decir que un instituto es el mismo luego de demostrar cómo ha cambiado todo en él, es jurídica y filosóficamente una inconsecuencia". En Derecho administrativo, parte 1, tomo III. Montevideo: 1950, pp. 133, 136 y 137. Confróntese en Contribución al estudio del Derecho administrativo. Montevideo: 1952, p. 175; y en Lo contencioso de anulación en el Derecho uruguayo. Montevideo: 1952, p. 117.

6 La Constitución de la República alude, a distintos efectos, a contratos celebrados por entidades estatales o por sus órganos, en los artículos 85 № 7), 124 № 1), 185 inciso 4ำ, 188 inciso 3oㅡㄴ 213, 289, 290 y 291 № 1). Por supuesto, también a nivel legal está consagrado que las entidades estatales celebran contratos. Baste citar las disposiciones legales recogidas en los artículos 33 y siguientes del tocaf.

7 Toda la doctrina que admite la existencia de contratos de la administración respalda esta afirmación muchas veces como un sobreentendido. Dentro de los límites de la doctrina nacional, debe señalarse, por supuesto, a Enrique Sayagues Laso, quien da por supuesto el efecto vinculante de los contratos: Tratado de Derecho administrativo, tomo I, séptima edición puesta al día por Daniel H. Martins. Montevideo: 1998, párrafos 348 y siguientes, pp. 439 y siguientes. Consideran explícitamente la cuestión Delpiazzo, Carlos E. Contratación administrativa. Montevideo: 1999, pp. 241-247; y "Contencioso de los contratos administrativos", en Anuario de Derecho Administrativo, tomo VIII, Montevideo, 2000, pp. 162-167; Durán Martínez, Augusto. "Ejecución de los contratos administrativos. Eficacia vinculante. El contrato como regla de Derecho. Mutabilidad del contrato". En Instituto Uruguayo de Derecho Administrativo. Contratación administrativa. Montevideo: 1989, pp. 59-75.

8 La Ley Orgánica del Tribunal de lo Contencioso Administrativo, decreto ley 15.524 del 9 de enero de 1984, artículo 23 apartado a), recogiendo la solución que ya había consagrado la ley 13.318 del 28 de diciembre de 1964, artículo 345, dispone que se considerarán objeto de la acción de nulidad "Los actos administrativos unilaterales, convencionales o de toda otra naturaleza dictados con desviación, abuso o exceso de poder, o con violación de una regla de derecho, considerándose tal, todo principio de derecho o norma constitucional, legislativa, reglamentaria o contractual".

9 Sentencia 417 del 22 de agosto de 1988, transcrita por Durán Martínez, A., en "Ejecución de los contratos administrativos", Ob. cit. p. 69; y por Cajarville Peluffo, Juan Pablo, en "Extinción de los contratos de la administración". En Instituto de Derecho Administrativo. Contratación administrativa. Montevideo: FCU, 1989, p. 123. Confróntese la sentencia 964 de primero de septiembre de 1999 del mismo tribunal.

10 El Tribunal de Cuentas es un órgano de control externo de la gestión financiera de todas las entidades estatales, independiente de los tres poderes del Estado, creado por la propia Constitución de la República (sección XIII, artículos 208-213), que actúa "con autonomía funcional" consagrada 
contratos de la administración al afirmar la existencia de un "principio de inmutabilidad" de tales contratos.

Así, por ejemplo, para citar un caso de pública notoriedad en nuestro país, el 3 de diciembre de 2003 el tribunal cuestionó la legitimidad de las modificaciones acordadas por las partes a una concesión de uso de un hotel municipal, que, en opinión de concedente y concesionario, había devenido inviable a raíz de las consecuencias de la crisis padecida en la región en 2002. Lo hizo invocando la inmutabilidad de los contratos de la administración y el principio de igualdad de los oferentes (considerandos $10,13,15,18)$ y, si bien había señalado como excepción la llamada "teoría de la imprevisión" (considerando 11), afirmó que "no se han configurado los requisitos que la doctrina más recibida exige para la aplicación de la teoría de la imprevisión, en suma se contraviene el principio de inmutabilidad de los Contratos de la Administración que garantiza el respeto al principio de igualdad de los oferentes, en mérito a los fundamentos ya señalados" (considerando 16). Finalmente (considerando 19), concluyó:

[...] que la mutabilidad de las normas sólo puede ser aceptada en tanto la misma sea prevista de antemano por el ordenamiento jurídico y siempre que no hayan derechos de terceros afectados (conforme Soto Kloss, ob. cit. página 223) [sic]. Si bien entre las excepciones al principio de inmutabilidad de los contratos consagrado por el Artículo 1291 del Código Civil se encuentra la precedentemente citada teoría de la imprevisión, en el caso no se configuran las características requeridas por la doctrina para su aplicación (considerando 13).

Reiteró su posición el 20 de mayo de 2004, ante la modificación acordada por las partes de los términos de una concesión de bienes portuarios en que se fijaban nuevos valores al canon y se sustituían algunas de las inversiones a las que se había obligado el concesionario, todo ello fruto también de nuevas circunstancias impuestas por la crisis.

El Tribunal de Cuentas resolvió "observar las modificaciones del contrato realizadas", para lo cual se fundó en que:

[...] en lo referente a la contratación original, mientras está vigente su plazo, no es admisible que se modifiquen las condiciones estipuladas, siendo aplicable por ello el principio de inmutabilidad de los contratos de la Administración, rigiendo en consecuencia la regla de pacta sunt

en la propia carta (artículo 210). Le compete, en cuanto ahora interesa, "intervenir en todo lo relativo a la gestión financiera" de todas las entidades estatales y en especial "intervenir preventivamente en los gastos y pagos" de esas entidades (artículo 211); sus potestades se limitan, en el primer caso, a "denunciar, ante quien corresponda, todas las irregularidades en el manejo de fondos públicos e infracciones a las leyes de presupuesto y contabilidad"; y, en el segundo, a formular "observaciones" sobre la legalidad de los gastos y pagos que, si no fueran atendidas, se comunicarán a la Asamblea General "a sus efectos". 
servanda de acuerdo con el Artículo 1291 del Código Civil que establece, que los contratos legalmente celebrados forman una regla a la cual deben someterse las partes como a la ley misma (considerando 4).

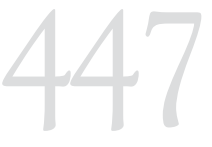

MUTABILIDAD

DE LOS

CONTRATOS DE LA ADMINISTRACIÓN

ENEL

DERECHO

URUGUAYO

MUTABILITY OF

MANAGEMENT

CONTRACTS IN

URUGUAYAN LAW

La doctrina incluye generalmente entre las llamadas "prerrogativas" de la administración contratante la de modificar los contratos que ha celebrado, razones de interés público de por medio. Así lo hacen, naturalmente, los autores que sostienen como principio general el de mutabilidad de los contratos de la administración, pero también aquellos que no proclaman expresamente ese principio e incluso los que lo rechazan y mantienen para estos contratos el principio de inmutabilidad ${ }^{12}$.

11 Así lo proclaman, por ejemplo, Garrido Falla, Fernando. Tratado de Derecho administrativo, volumen II. Madrid: 1992, pp. 87-88; Barra, Rodolfo Carlos. Contrato de obra pública, tomo I. Buenos Aires: 1984, pp. 54-56; Dromi, Roberto. Licitación pública. Buenos Aires: 1995, pp. 29, 505 y 519; Escola, Héctor Jorge. Tratado integral de los contratos administrativos, volumen I. Buenos Aires: 1977, pp. 391-396; y Brewer-Carias, Allan R. Contratos administrativos. Caracas: 1997, p. 160. Por su lado, García de Enterría y Fernández concluyen que, en la contratación administrativa, "la inmutabilidad del contrato no es una inmutabilidad del contenido, sino del fin, que prima en todo caso sobre aquél". García de Enterría, Eduardo y Tomás-Ramón Fernández. Curso de Derecho administrativo, volumen I. Madrid: 2002, p. 740. Conformes con este enfoque existen sentencias del Tribunal Supremo español; véase Santamaría Pastor, Juan Alfonso y Luciano Parejo Alfonso. Derecho administrativo. La jurisprudencia del Tribunal Supremo. Madrid: 1992, p. 412, nota 60, y p. 417 , notas 70 y 71 .

12 Sobre el tema en la doctrina uruguaya, véase Sayagués Laso, E. Tratado ..., tomo I. Ob. cit., párrafos 389 y 390, pp. 473-475; Delpiazzo, C.E. Contratación administrativa. Ob. cit., pp. 216-219; Durán Martínez, A. "Ejecución de los contratos administrativos". Ob. cit., pp. 63-75; Vázquez, Cristina. Modalidades de ejecución de la obra pública. Montevideo: 1992, pp. 74-76; Cajarville Peluffo, J.P. "Extinción de los contratos...". Ob. cit., pp. 123 y siguientes. En la doctrina extranjera, véase Jeze, Gastón. Principios generales del Derecho administrativo, tomo IV. Buenos Aires: 1950, pp. 230235; De Laubadere, André, Jean-Claude Venezia e Yves Gaudemet. Traité de Droit Administratif, tomo I. París: 1996, pp. 768-770 y 772; Rivero, Jean. Droit Administratif. París: 1975, pp. 123-124 y 126; Vedel, Georges. Droit Administratif. París: 1976, pp. 252-253 y 255-256; Chapus, René. Droit Administratif Général, tomo 1. París: 1988, pp. 748-749; Garrido Falla, F. Tratado de Derecho administrativo. Ob. cit., pp. 91-92; García de Enterría, E. y R. Fernández. Curso de Derecho administrativo. Ob. cit., pp. 692-693, 732-733 y 735-743; Parada, Ramón. Derecho administrativo, tomo I. Madrid: 1993, pp. 280-283; Santamaría Pastor, J.A. y L. Pareja Alfonso. Derecho administrativo. La jurisprudencia... Ob. cit., pp. 417-420; Bandeira de Mello, Celso Antonio. Curso de Direito Administrativo. São Pablo: 2004, pp. 579-580; Brewer-Carias, A.R. Contratos administrativos. Ob. cit., pp. 48-49, 160 y 169-182; Marienhoff, Miguel S. Tratado de Derecho administrativo, tomo III-A. Buenos Aires: 1974, pp. 314, 395-403; Cassagne, Juan C. "La sustantividad del contrato administrativo y sus principales consecuencias jurídicas". En Estudios de Derecho público. Buenos Aires: 1995, pp. 128-129; Dromi, R. Licitación pública. Ob. cit., pp. 29, 505-506 y 519; y Escola, H.J. Tratado integral de los contratos... Ob. cit., pp. 391-400. 
La conciliación de esos términos en principio aparentemente contradictorios - eficacia vinculante y mutabilidad de un contrato- requiere examinar separadamente los modos, los motivos, los fines y los límites con que la modificación del contrato puede ocurrir legítimamente.

\section{LOS MODOS DE LA MODIFICACIÓN CONTRACTUAL}

Los modos en que la modificación puede producirse, entendiendo por tales las distintas formas o actos jurídicos a través de los cuales ella ocurre, pueden consistir en: (a) la decisión unilateral de la administración o el mutuo acuerdo de los contratantes, que supone un acto unilateral anterior, expreso o implícito, y que admiten celebrarlo; (b) la decisión jurisdiccional; o (c) también puede suceder que las modificaciones ocurran de pleno derecho.

En un Derecho como el uruguayo, donde no la consagra a texto expreso sino muy limitadamente ${ }^{13}$, la admisión — como "prerrogativa" de la administración contratante - de la potestad de modificar unilateralmente los contratos que ha celebrado con razones de interés público de por medio solo puede fundarse en su reconocimiento como un "poder implícito" del órgano competente para contratar.

La atribución de cometidos a una entidad estatal supone no solo la facultad sino el deber de cumplirlos; por ello, conforme al "principio de los poderes implícitos", la atribución expresa de cometidos a un órgano público supone implícitamente la atribución de los poderes necesarios para cumplirlos adecuadamente, siempre que el uso de tales poderes no le esté prohibido directa o indirectamente, ni esté atribuido expresamente a otro órgano público ${ }^{14}$. El reconocimiento —como un poder

13 La única disposición legal que reconoce genéricamente la potestad de la administración de modificar unilateralmente sus contratos es el artículo 63 del tocaf (ley 15.903, artículo 517, redición ley 16.320, de 1-XI-992, artículo 400), que dispone:

"Las prestaciones objeto de los contratos podrán aumentarse o disminuirse, respetando sus condiciones y modalidades y con adecuación de los plazos respectivos, hasta un máximo de $20 \%$ (veinte por ciento) o del 10\% (diez por ciento) de su valor original en uno y otro caso y siempre que el monto definitivo no sobrepase el límite máximo de aprobación para el cual está facultada la respectiva autoridad. Cuando exceda ese límite deberá recabarse la aprobación previa de la autoridad competente. También podrán aumentarse o disminuirse en las proporciones que sea de interés para la administración y que excedan de las antes indicadas, con acuerdo del adjudicatario y en las mismas condiciones preestablecidas en materia de su aprobación. En ningún caso los aumentos podrán exceder el 100\% (cien por ciento) del objeto del contrato".

14 Korzeniak, José. Las comisiones parlamentarias de investigación y sus facultades. Montevideo: 1998, pp. 84-86. Véase también Jiménez De Arechaga, Justino. La Constitución Nacional, tomo II. Montevideo: 1997, p. 306; Barbagelata, Aníbal L. "Separación preventiva de directores e intervención de un ente autónomo". Revista D.J.A., tomo 62, Montevideo, p. 177; Aguirre Ramírez, Gonzalo. "La competencia del Poder Ejecutivo en la Constitución Nacional de 1967". Revista D.J.A., tomo 67, Montevideo, 1969, p. 151-152; Cajarville Peluffo, Juan Pablo. "Invalidez de los actos administrativos en la ley 15.524". En Dos estudios de Derecho administrativo, Montevideo: 1988, p. 81, nota 15; Risso Ferrand, Martín. Derecho constitucional, tomo I. Montevideo: 2005, pp. 444-445; Suprema Corte de Justicia, sentencias 797 y 801 del 16 de octubre de 1995. Anuario de Derecho Administrativo, tomo VII, Montevideo, 1999, pp. 288-289, № 221; sentencia 77 del 26 de marzo de 2004. L.J.U., tomo 131, Montevideo, 2005, caso 15.044, p. J-264, citando la anterior № 82-91. Sobre el principio en el Derecho comparado, véase García-Pelayo, Manuel. Derecho constitucional comparado. Madrid: 1984, p. 363-367; 
implícito- de la prerrogativa de modificación unilateral por la administración de los contratos que ha celebrado exigirá el cumplimiento de esos tres requisitos de principio. La necesidad de ejercer ese poder para cumplir adecuadamente el cometido deberá verificarse caso por caso. Ya se ha señalado la inexistencia de atribución expresa del poder de modificar los contratos en el Derecho positivo uruguayo, con la salvedad de su limitado reconocimiento. La inexistencia de prohibición directa o indirecta del ejercicio de tal potestad requiere un examen más detenido.

Se han invocado como normas obstativas, en primer lugar, los ya señalados artículos 1291 del Código Civil y 209 del Código de Comercio, que en cuanto atañe a las partes parecen asimilar el contrato a la ley. En verdad, esas disposiciones no van más allá de una comparación metafórica para explicar la eficacia vinculante del contrato, pero es obvio que no significan asimilar el valor y la fuerza del contrato a los de la ley, ni siquiera para los contrayentes. Esa eficacia no obsta, por de pronto, a que las partes modifiquen de común acuerdo el contrato; la libertad con que pueden acordarlo los contratantes privados no es asimilable a la discrecionalidad de la que pueda estar dotada para ello la administración, porque sobre ella recaen, según se verá, límites que no constriñen a aquellos. En todo caso, lo relevante ahora consiste en señalar que la indiscutible eficacia vinculante de los contratos no resuelve por sí sobre la posibilidad o la imposibilidad de su modificación, que depende de otras reglas del Derecho.

Algo similar ocurre cuando se invoca, como obstativa de la modificación de los contratos por la administración, la inclusión de "toda norma contractual" entre las reglas de Derecho que la vinculan, en el artículo 23, apartado a), del decreto ley 15.524. Pese a la eficacia vinculante de todas ellas, las reglas de Derecho allí enunciadas son susceptibles de modificación, cada una en la forma que corresponda, algunas - las reglamentarias - por la propia administración. La eficacia vinculante de esas reglas de Derecho no obsta a su modificación, y esta no es cuestión que resuelva la mentada disposición legal.

Tampoco el artículo 63 del tocaf puede interpretarse como norma prohibitiva de la modificación de sus contratos por la administración fuera de los casos allí previstos expresamente. Para admitir esa interpretación a contrario debería demostrarse que el principio - al que ese artículo haría excepción- consiste en la prohibición ${ }^{15}$, lo cual es dar

Bidart Campos, Germán J. El Derecho constitucional del poder, tomo I. Buenos Aires: 1967, pp. 348350; Bianchi, Alberto A. La delegación legislativa. Buenos Aires: 1990, pp. 52-56.

$15 \mathrm{El}$ argumento a contrario solo es procedente cuando se está interpretando una norma que hace excepción a un principio general. Véase Cajarville Peluffo, Juan Pablo. "Contencioso administrativo de reparación patrimonial”. Revista Uruguaya de Derecho Procesal, № 1-1989, Montevideo, p. 25; y Recursos administrativos. Montevideo: 2000, pp. 32-33, así como la bibliografía que allí se cita.

MUTABILIDAD

DELOS

CONTRATOS DE LA

ADMINISTRACIÓN

ENEL

DERECHO

URUGUAYO

MUTABILITY OF

MANAGEMENT

CONTRACTS IN

URUGUAYAN LAW 
por demostrado a priori precisamente lo que se quiere demostrar, vicio de razonamiento al que no son ajenos los dos argumentos anteriores. En verdad, el artículo 63 en cuestión está limitando la modificación cuantitativa del objeto de los contratos, cuando ella sea procedente en virtud del reconocimiento de un poder implícito de la administración en tal sentido.

Se trata tan solo de distinguir entre la violación y la modificación de una regla de Derecho cumpliendo los requisitos formales y sustanciales para ello. La eficacia vinculante de esas reglas ilegitima la primera, pero no obsta a la segunda.

La potestad de modificar un contrato, conforme con el "principio de los poderes implícitos”, deberá en conclusión reconocerse al órgano contratante incluso a falta de texto expreso cuando, por motivos supervinientes que serán los que justifiquen el ejercicio de tal potestad, sus términos le impidan a la administración cumplir conforme con el Derecho y con los criterios de buena administración ${ }^{16}$ el cometido para el cual aquel se celebró.

Admitida como implícita la potestad de modificación unilateral, obviamente deberá reconocerse, en las mismas condiciones y con iguales requisitos, la potestad de acordar con el cocontratante la modificación del contrato que los vincula ${ }^{17}$. En tal caso, un nuevo acto contractual sustituirá en lo pertinente las previsiones del anterior. Pero ese acuerdo de voluntades supone un acto administrativo unilateral anterior mediante el cual se admite celebrarlo, que podrá ser expreso o estará implícito en la manifestación de voluntad que perfecciona el nuevo consentimiento.

Esto último pone de manifiesto que, en ambos casos, el tema que se trata es propio de la teoría del acto administrativo, porque tanto el acto de la administración que dispone unilateralmente la modificación de un contrato como el que en su caso concurre a perfeccionar un nuevo contrato con ese contenido deben cumplir los requisitos de legitimidad comunes a todos los actos administrativos. Ambos serán "actos separables de los contratos”, anulables por el Tribunal de lo Contencioso Administrativo

Además, Carnelutti, Francesco. Sistema de Derecho procesal civil, tomo I. Buenos Aires: 1944, p. 126; Cassinelli Muñoz, Horacio. "La apelación para ante la Asamblea General según el artículo 303 de la Constitución", Revista D.J.A., tomo 55, Montevideo, p. 133; Kalinowsky, Georges. Introducción a la lógica jurídica. Buenos Aires: 1973, pp. 176-179; y Klug, Ulrich. Lógica jurídica. Bogotá: 1998, pp. 176-184.

16 La Constitución uruguaya recoge en el artículo 311 el concepto de "buena administración" para conferir "efectos generales y absolutos" a la sentencia anulatoria de un acto administrativo ilegítimo por violatorio de una regla de Derecho. "Buena administración significa perseguir los fines objeto de la función pública, del modo más idóneo y más conveniente. Esto es, la actividad debe cumplirse en la forma más oportuna y más adecuada para la obtención de aquellos fines". Giorgi, Héctor. "El mérito y la validez del acto administrativo. El concepto de buena administración en la Constitución". En Escritos jurídicos. Montevideo: 1976, p. 92.

17 Delpiazzo, Carlos E. "Renegociación de las tarifas de los servicios públicos concedidos". Anuario de Derecho Administrativo, tomo XI, Montevideo, 2004, pp. 21-30. 
según expresa previsión del decreto ley 15.524, "Orgánico del TCA", artículo 23, apartado b), a instancia del titular de un derecho o de un interés directo, personal y legítimo violado o lesionado por el acto, por las mismas causales de ilegitimidad que habilitan la anulación de cualquier acto administrativo (Constitución, artículos 309 y siguientes) ${ }^{18}$.

Particular interés reviste, en este aspecto, la existencia de motivos que, como presupuestos de hecho, justifiquen razonablemente el dictado del acto que disponga o admita la modificación del contrato, y la legitimidad de la finalidad o del designio perseguido por la administración al dictarlo. La administración no puede disponer ni consentir una modificación del contrato sin motivos o por motivos falsos con la exclusiva finalidad de favorecer al cocontratante o con cualquier otra finalidad que no sea propia del servicio, todo lo cual no es sino aplicación de principios generales que rigen la actividad administrativa.

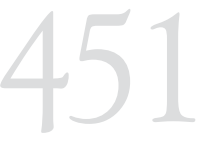

MUTABILIDAD DELOS

CONTRATOS DE LA ADMINISTRACIÓN ENEL DERECHO URUGUAYO

MUTABILITY OF MANAGEMENT CONTRACTS IN URUGUAYAN LAW

La modificación por acto jurisdiccional ocurrirá cuando ella sea debida en virtud de circunstancias de hecho ocurridas y la administración se resista a disponerla o acordarla.

La modificación de pleno derecho ocurrirá, por ejemplo, cuando una obligación de alguna de las partes se extinga por la ocurrencia de un caso de fuerza mayor insuperable que haga imposible su cumplimiento, siempre que esa extinción no acarree la del contrato en sí mismo.

\section{LOS MOTIVOS DE LA MODIFICACIÓN CONTRACTUAL}

Todo acto administrativo — en verdad, todo acto jurídico- se dicta en virtud de la ocurrencia de determinadas circunstancias de hecho, que a su vez operan como supuestos de hecho de su dictado y que, con una terminología consagrada en nuestro país por doctrina y jurisprudencia, se denominan motivos del acto $^{19}$.

18 Giorgi, Héctor. El contencioso administrativo de anulación. Montevideo: 1958, pp. 55-58; Méndez, A. Lo contencioso de anulación en el Derecho uruguayo. Ob. cit., pp. 117 y 201-202; Real, Alberto R. "Contencioso de los contratos administrativos". En Revista de la Facultad de Derecho y Ciencias Sociales, año XVIII, № 1-2, Montevideo, 1967, p. 297 y siguientes; Sayagués Laso, Enrique. Tratado de Derecho administrativo, tomo II. Montevideo: 1998, pp. 468-469; Cajarville Peluffo, Juan P. Recursos administrativos. Ob. cit., pp. 104-105; Hutchinson, Tomás. Ley nacional de procedimientos administrativos, tomo II. Buenos Aires: 1988, p. 266. Sobre el concepto de "acto separable" del Tribunal de lo Contencioso Administrativo, véase la sentencia de 11-XII-985, L.J.U., tomo 93, caso 10.572, p. 24; la sentencia 1071 de 13-X-95 en el Anuario de Derecho Administrativo, tomo VII, № 100, Montevideo, 1999, pp. 233-234. Sobre la admisión por el tribunal de la procesabilidad de "actos separables", véase la sentencia 343 de $29-\mathrm{IX}-86$ en el Anuario de Derecho Administrativo, tomo I, № 72 y 73, 1987; la sentencia 512 de 27-VI-94, también en el Anuario, tomo VI, № 184, 1998; la sentencia de 23-II-94 en L.J.U., tomo 112, caso 12.871, p. 105; la sentencia 599 de 1998 en el Anuario, tomo IX, № 291, 2002; y las sentencias 381 y 585 de 2002, Anuario, tomo XI, № 281 y 282 , 2004.

19 Sayagués Laso, E. Tratado de Derecho administrativo. Ob. cit., párrafos 277 y 278, pp. 369 a 372; Cajarville Peluffo, J.P. "Invalidez de los actos...”. Ob. cit., pp. 85-86. 
El contenido del acto aparece así como la consecuencia jurídica imputada por el órgano competente a la circunstancia de hecho invocada como su motivo. En todo caso, el acontecer de los hechos es una circunstancia exterior cuya existencia se impone objetivamente y desde fuera a la administración, circunstancia de la cual el ejercicio del poder de dictar el acto aparecerá como consecuencia jurídica. Por tanto, en cuanto a la apreciación de la existencia o inexistencia en sí misma de los hechos y su valoración jurídica (legitimidad o ilegitimidad), la administración no goza de discrecionalidad alguna. Si los hechos operantes como supuesto normativo o como motivos del acto administrativo no existen o no son como la administración pretende, el acto estará viciado por inexistencia de motivos. Si los hechos son como la administración pretende, pero no caben en el supuesto (determinado o indeterminado) de la norma atributiva del poder de dictar el acto, este estará viciado por ilegitimidad de los motivos.

Además, para que el acto sea legítimo, no basta con la existencia y correcta calificación jurídica de los hechos que lo motivan: es necesario que su contenido sea razonablemente adecuado a tal supuesto de hecho. Ciertos supuestos ameritan determinadas consecuencias y no otras: una infracción, por ejemplo un incumplimiento contractual, amerita una sanción y no un premio. Debe existir, asimismo, proporcionalidad entre el supuesto de hecho y lo dispuesto por el acto. La inadecuación del contenido dispositivo del acto a su presupuesto de hecho o motivo configura el vicio que nuestra legislación denomina "abuso o exceso de poder"20, y su contralor por el contencioso administrativo anulatorio es afirmado por la jurisprudencia de nuestro Tribunal de lo Contencioso Administrativo más reciente ${ }^{21}$, siguiendo los pasos de la mejor doctrina ${ }^{22}$.

20 Decreto ley 15.524 del 9 de enero de 1984, Ley Orgánica del Tribunal de lo Contencioso Administrativo, artículo 23 apartado a). Cajarville Peluffo, J.P. "Invalidez de los actos...". Ob. cit., pp. 95-96, 109-117 y 114-115. Nuestra doctrina no ha acordado sobre el criterio para distinguir el "abuso" del "exceso" de poder; véase Durán Martínez, Augusto. "Desviación, abuso y exceso de poder". En Estudios de Derecho administrativo. Montevideo: 1999, pp. 131-134; Cagnoni, José A. "Desviación, abuso y exceso de poder como causas de nulidad de los actos administrativos"; y Cassinelli Muñoz, Horacio. Intervención en el tema "Desviación, abuso y exceso de poder como causas de nulidad de los actos administrativos". Ambos en Tercer coloquio. Contencioso de Derecho público. Responsabilidad del Estado y jurisdicción. Montevideo: 1997, pp. 45 y siguientes, y p. 58 respectivamente. El tema reviste interés tan solo académico y carece de toda relevancia práctica porque ambos vicios producen las mismas consecuencias jurídicas.

21 En materia de sanciones, véanse las sentencias de 1991 y 1992 en el Anuario de Derecho administrativo, tomo V, № 142, 224, 422, 424, 426, 429, 430, 483-486, 488-495, 1996; las sentencias de 1993 y 1994 en el tomo VI, № 267-289, 327-333; las sentencias de 1995 en el tomo VII, № 145, 146, 150 y 151 ; las sentencias de 1996 y 1997 en el tomo VIII, № 306-311, 313-321, 361, 363-368, 370-375 y 621 ; las sentencias de 1998 y 1999 en el tomo IX, № 308-318, 355, 357, 358, 360-363; y las sentencias de 2000 en el tomo X, № 114, 201-205, 259, 261, 264, 266, 269, 270 y 272 . En otras materias, y siempre en el Anuario, véanse las sentencias de 1991 y 1992 (tomo V, № 128, 131, 140, 487, 974, 977 y 978), de 1993 y 1994 (tomo VI, № 77, 84, 85, 633, 634, 636 y 637), de 1998 y 1999 (tomo IX, № 140, 142, 149,151 y 592) y la de 2000 (tomo X, № $112,113,492,495-497$ ).

22 Sayagués Laso, E. Tratado... Ob. cit., p. 341, nota 4; Gianola Martegani, Ariel. "Los límites de la potestad disciplinaria: razonable adecuación de la sanción a la falta" y "Nuevamente sobre el control del grado de la sanción". Ambos textos en Revista D.J.A., tomo 72, Montevideo, 1972, p. 155 y siguientes, y tomo 73, 1973, p. 150 y siguientes respectivamente; Cajarville Peluffo, J.P. "Invalidez de los actos...". Ob. cit., p. 106. En la doctrina y jurisprudencia extranjeras puede verse 
Tratándose de actos administrativos cuyo contenido consista en disponer o consentir la modificación de un contrato administrativo anterior, los motivos por los cuales las estipulaciones contractuales impiden a la administración cumplir conforme a Derecho y a criterios de buena administración el cometido para el cual aquel se celebró, que legitimarán su dictado conforme al "principio de los poderes implícitos", deberán ser supervinientes a su celebración, o en su caso a la presentación de las ofertas si hubiese existido un procedimiento competitivo de selección del cocontratante. En todo caso, deberán ser circunstancias que no se tuvieron en cuenta, por no existentes o no conocidas, al contratar. De lo contrario, no justificarán razonablemente el mantenimiento, aun modificado, del contrato.

Tales circunstancias consistirán, a vía de ejemplo, en modificaciones en las condiciones técnicas de prestación de los servicios o de realización de las obras comprometidas, cambios en la situación económica general o particular del sector, en especial modificaciones de la oferta o de la demanda de servicios similares, modificaciones del régimen jurídico de la actividad de que se trate, o genéricamente inidoneidad de los servicios o las obras tal como fueron previstos en el contrato para satisfacer las necesidades a que están destinados ${ }^{23}$. Este último motivo conduce a la consideración del fin legítimo del acto modificatorio de un contrato.

\section{V.LOS FINES DEBIDOS DE LAMODIFICACIÓN CONTRACTUAL}

En toda materia, la administración solo puede actuar para perseguir los fines que el propio orden jurídico le impone $\mathrm{e}^{24}$. $\mathrm{Al}$ respecto, no basta afirmar que el acto administrativo solo es legítimo si se ha dictado en pro del interés general, sino que esa noción genérica se concreta en cada

Corte Suprema de Justicia de la Nación Argentina. Sentencia de 22.VI.1960, caso del Cine Callao (en relación con la constitucionalidad de la ley). En Gordillo, Agustín. Tratado de Derecho administrativo, tomo II. Buenos Aires: 1975, pp. XII-35-50; Durán Martínez, Augusto. "Proporcionalidad entre la falta y la sanción", comentando jurisprudencia del Consejo de Estado francés sobre el error manifiesto de apreciación. Revista Uruguaya de Estudios Administrativos, № 1-1980, Montevideo, pp. 127 y siguientes; García de Enterría, E. y R. Fernández. Curso de Derecho administrativo, tomo I. Ob. cit., pp. 476-477. Refiriendo a la jurisprudencia del Tribunal Supremo, véase Gordillo, Agustín. Tratado de Derecho administrativo, tomo III. Buenos Aires: 1979, pp. VIII-14-16; y Linares, Juan F. Razonabilidad de las leyes. Buenos Aires: 1970, p. 151

23 Delpiazzo, C.E. "Renegociación de las tarifas...". Ob. cit., p. 26.

24 Justino Jiménez de Arechaga señala que todos los poderes de todos los órganos del Estado están sometidos a limitaciones de competencia, forma, fondo y fines, que resultan del fundamento mismo del régimen institucional: artículos 4 y 82 (numeración de la Constitución de 1967). En La Constitución Nacional, tomo I, Montevideo: 1992, p. 182; tomo II, Ob. cit., p. 48; tomo VIII, p. 151; y tomo X, p. 7. Cassinelli Muñoz, Horacio. "El ajuste de la administración a las sentencias jurisdiccionales". Revista D.J.A., tomo 55, 1957, Montevideo, p. 70-71; intervención en Jornadas Latinoamericanas de Derecho Procesal. Revista de la Facultad de Derecho y Ciencias Sociales, año IX, № 1, Montevideo, 1958, p. 151; y "El interés legítimo como situación jurídica garantida en la Constitución uruguaya". En Perspectivas del Derecho público en la segunda mitad del siglo XX, tomo III. Madrid: 1969, p. 299. También véase Sayagués Laso E. Tratado de Derecho... Ob. cit., p. 373; Méndez, A. Lo contencioso... Ob. cit., p. 171-172; Zanobini, Guido. Corso di Diritto Amministrativo, tomo I. Milán: 1947, pp. 24-26; Cajarville Peluffo, J.P. "Invalidez de los actos...”. Ob. cit., pp. 81-82. 
caso y permite delimitar el fin para el cual le ha sido conferida la singular potestad de la que se trate ${ }^{25}$.

Ese fin debido puede estar explícitamente establecido en las normas en cuestión, y lo está muchas veces, pero con más frecuencia aparecerá solo implícitamente. En todo caso, su delimitación es una cuestión de interpretación o de integración de la norma de competencia, realizable por las técnicas usuales también positivamente consagradas (Código Civil, artículos 16 a 20), y para ello se tiene presente el designio que muchas veces el legislador encuentra predeterminado en la propia ley fundamental ${ }^{26}$.

Cuando la administración, al ejercer la potestad de que se trate, dicta un acto administrativo, en tanto en la base de la voluntad jurídica del órgano existe una expresión de voluntad psicológica del o los titulares del órgano, esta voluntad conlleva siempre un fin, como intención, propósito, objetivo o designio, porque es propio de la voluntad humana querer para una finalidad. El acto aparece así como el medio utilizado por el agente para lograr el fin que se propone. Este fin efectivamente contenido en el acto como representación psicológica o subjetiva por el titular del órgano de un efecto o resultado final ${ }^{27}$ efectivamente procurado - que puede denominarse fin querido — debe coincidir con el fin debido impuesto por la regla de Derecho atributiva de la competencia. La no coincidencia del fin querido con el debido configura la desviación de poder ${ }^{28}$, vicio del acto que produce su invalidez (Constitución, artículo 309; decreto ley 15.524, artículos 23, apartado a).

Como ocurre con los motivos, tampoco basta para valorar la legitimidad del acto con examinar el fin querido por el autor del acto en sí mismo y en su relación o concordancia con el debido. Es preciso además analizar la idoneidad de su contenido dispositivo para lograr el fin debido impuesto normativamente. La razonable idoneidad de la actividad administrativa para el fin debido constituye en nuestro Derecho un requisito de legitimidad ${ }^{29}$, y su contralor jurisdiccional adquiere

25 García de Enterría, E. y R. Fernández. Curso de Derecho... Ob. cit., p. 552; Prat, Julio A. De la desviación de poder. Montevideo: 1957, p. 149; 1976, pp. 46-47 y 63.

26 Por ejemplo, los artículos $33,34,40,41,45,47,50,53,85$, № $3^{\circ}$, etcétera, de la Constitución.

27 No se habla aquí del efecto o resultado inmediato del acto, que se confunde con su eficacia formal. El efecto o resultado inmediato de una destitución es la desinvestidura del funcionario, la extinción de la relación funcional. El efecto o resultado final de que se habla en el texto (fin querido) puede ser el mantenimiento de la disciplina en el servicio, la obtención de economías presupuestales, el beneficio al funcionario que le sigue en el escalafón o la satisfacción de una inquina personal.

28 Sayagués Laso E. Tratado de Derecho... Ob. cit., pp. 373-380; Prat, J.A. De la desviación de poder. Ob. cit., 1957, pp. $182-187$ y 370 , y 1976, pp. $45-49$ y 169; Cajarville Peluffo, J.P. "Invalidez de los actos...". Ob. cit., p. 90.

29 Confróntese Frugone Schiavone, Héctor. "Control de la discrecionalidad administrativa, principios generales de derecho y abuso de poder". Revista D.J.A., tomo 72, Montevideo, 1972, pp. 155-168; y "La discrecionalidad administrativa". Revista de la Facultad de Derecho y Ciencias Sociales, año XXVI, № 1, Montevideo, 1982, p. 103; además, Cajarville Peluffo, J.P. "Invalidez de los actos...". Ob. cit., pp. 96 y $107-109$. 
primordial importancia frente a la actuación de la administración contemporánea $^{30}$. La actividad administrativa, en cuanto medio para la obtención de un fin, debe ser apta o idónea para obtenerlo ${ }^{31}$ y esta es una cuestión de legitimidad y no de mérito, porque la vinculación de la administración al fin debido también es cuestión de legitimidad y no de mera buena administración ${ }^{32}$ (Constitución, artículo 309; decreto ley 15.524, artículo 23, apartado a). Si la actuación en pos del fin legítimo es un deber jurídico y no solo un principio de buena administración o de moralidad administrativa, la utilización de medios probadamente inaptos o inidóneos implica necesariamente incumplimiento de ese deber jurídico y, por tanto, ilegitimidad del comportamiento administrativo, que configura el vicio que nuestra legislación denomina "abuso o exceso de poder"33, y no simple demérito ${ }^{34}$.

Cuando el contenido del acto administrativo dispone o consiente la modificación de un contrato anterior de la administración, el fin debido será el mismo del contrato que se modifica: satisfacer el interés público concreto para el cual aquel se celebró ${ }^{35}$.

Si el contrato originario estaba viciado por desviación de poder, la irregularidad será insubsanable y del mismo vicio adolecerá el acto administrativo que tienda a su modificación. Si el vicio consiste en la inidoneidad del contenido originario del contrato para lograr el fin debido, las modificaciones a ese contenido deberán tender a subsanar esa ineptitud para lograr la satisfacción de las necesidades de interés público a las que el contrato está instrumentalmente destinado ${ }^{36}$.

30 Cajarville Peluffo, J.P. "El Poder Ejecutivo como conductor de políticas sectoriales en la legislación uruguaya". En Estudios de Derecho administrativo. Publicación en homenaje al centenario de la creación de la Cátedra, tomo II. Montevideo: 1979, pp. 101-103.

31 Confróntese Brito, Mariano. "De la naturaleza y objeto del control a cargo del Tribunal de lo Contencioso Administrativo". Revista D.J.A., tomo 73, Montevideo, 1973, pp. 55-56; y "De la razonabilidad del acto administrativo: la cuestión de su contralor jurisdiccional anulatorio". Revista de la Facultad de Derecho y Ciencias Sociales, año XXIII, № 3-4, Montevideo, 1975, pp. 171-183.

32 En cuanto a esto último, confróntese Cassinelli Muñoz, H. "El interés legítimo....". Ob. cit., p. 299.

33 Decreto ley 15.524 del 9 de enero de 1984, "Ley Orgánica del Tribunal de lo Contencioso Administrativo", artículo 23 apartado a). En Cajarville Peluffo, J.P. "Invalidez de los actos...". Ob. cit., pp. 96 y 109-115.

34 Confróntese Frugone Schiavone, H. "La discrecionalidad administrativa". Ob. cit., p. 104. Véase Brito, Mariano. "La aptitud del acto administrativo para el fin debido: supuesto de principio en que reposa la discrecionalidad". En Estudios de Derecho administrativo, tomo II. Montevideo: 1979, pp. 29-42; Corte Suprema de la Nación Argentina, sentencia de 22.VI.1960, caso del Cine Callao (en relación con la constitucionalidad de la ley). En Gordillo, A. Tratado..., tomo II. Ob. cit., pp. XII-35-50; Forsthoff, Ernst. Tratado de Derecho administrativo. Madrid: 1958, pp. 336-337; García de Enterría, E. y R. Fernández. Curso..., tomo I. Ob. cit., pp. 552-556; Gordillo, A. Tratado..., tomo III. Ob. cit., pp. VIII14-15 y 30; Haro, Ricardo. "Control de razonabilidad y poder de policía". En Estudios de Derecho administrativo, tomo I. Ob. cit., p. 202; Linares, J. F. Razonabilidad... Ob. cit., pp. 137-139; Wolf, H.J. "Fundamentos del Derecho administrativo de prestaciones". En Perspectivas del Derecho público en la segunda mitad del siglo XX, tomo V. Madrid: 1969, p. 382.

35 Brewer-Carias, A.R. Contratos administrativos. Ob. cit., p. 176.

36 García De Enterría, E. y R. Fernández. Curso de Derecho... Ob. cit., p. 733. Dicen los autores: "Si para conseguir estos fines, implícitos en el contrato y connaturales al mismo, es necesario adaptar a las nuevas necesidades los términos de lo pactado, esta adaptación es obligada. La inalterabilidad del fin impone o puede imponer la alteración parcial o, mejor aún, la adaptación del objeto". 


\section{LOS LÍMITES DE LA MODIFICACIÓN DE LOS CONTRATOS}

Naturalmente, la posibilidad de modificar los contratos de la administración tiene límites. En principio, la potestad de la administración de disponer o consentir la modificación del contrato que ha celebrado es discrecional $^{17}$, de manera que el órgano competente tendrá legítimamente la posibilidad de elegir, entre todas las soluciones admitidas por Derecho como contenido del contrato, aquella que entienda más adecuada a los motivos que justifican la modificación y más idónea para satisfacer las necesidades de interés público a que tiende el contrato como fin debi$\mathrm{do}^{38}$. Esa elección se deberá realizar conforme a criterios técnicos, éticos, axiológicos, políticos y también jurídicos, establecidos estos últimos por reglas de Derecho que, sin eliminar la posibilidad de optar entre diversas soluciones, consagran pautas o modos de comportamiento, que son flexibles y apreciables caso por caso en cada circunstancia ${ }^{39}$. Instrumentos de técnica jurídica que permiten establecer este tipo de pautas de comportamiento flexibles para los órganos públicos son, entre otros, el acogimiento expreso de los "principios generales de Derecho" como "reglas de Derecho" integrantes del ordenamiento jurídico ${ }^{40}$; la remisión a los llamados standards jurídicos, en particular el de "razonabilidad" consagración genérica de la "desviación, abuso o exceso de poder" como "vicios" invalidantes de la actividad pública, con lo cual se impone por reflejo la necesidad de comportamientos que eviten su configuración ${ }^{42}$.

Con esos límites, y respetando además las limitaciones que puedan establecer normas expresas ${ }^{43}$, la modificación puede recaer sobre

37 Barra, Rodolfo C. Contrato de obra pública, tomo 3. Buenos Aires: 1988, p. 1071.

38 Sayagués Laso E. Tratado de Derecho administrativo... Ob. cit., p. 338; Cajarville Peluffo, J.P. "Invalidez de los actos...". Ob. cit., pp. 83-85 y 100.

39 Cajarville Peluffo, J.P. Ibíd., p. 100. Confróntese, específicamente en cuanto a los límites de la modificación unilateral de los contratos, Brewer-Carias, A.R. Contratos administrativos. Ob. cit. pp. 175 y $180-182$.

40 Constitución, artículo 332; Código Civil, artículo 16; decreto ley 15.524 del 9 de enero de 1984, artículo 23 apartado a), que repite la solución de la ley 13.318 del 28 de diciembre de 1964, artículo 345. En la doctrina nacional, véasde Real, Alberto Ramón. "Los principios generales de derecho en la Constitución uruguaya". Revista de Derecho Público y Privado, tomo 40, Montevideo, 1958, pp. 195-247. Se publicó en apartado una versión actualizada y con un apéndice: "Los principios generales de Derecho en la Constitución Uruguaya - Principio de igualdad de remuneración por igual trabajo" (1965), reproducido en Estado de Derecho y humanismo personalista. Montevideo: FCU, 1974, pp. 5-93; "Los principios generales de Derecho...". Ob. cit., pp. 173-223; "Los principios del procedimiento administrativo en el Uruguay". Revista de la Facultad de Derecho y Ciencias Sociales, año XXIII, № 3-4, Montevideo, 1975, pp. 347-374; y Nuevos estudios de Derecho administrativo. Montevideo: Acali, 1976, pp. 5-40. También véase Barbe Pérez, Héctor. "Los principios generales de Derecho como fuente de Derecho administrativo en el Derecho positivo uruguayo". En Estudios jurídicos en memoria de Juan José Amézaga. Montevideo: 1958, pp. 35-55; Cajarville Peluffo, J.P. Reflexiones sobre los principios generales... Ob. cit., pp. 155-179. Todos los trabajos anteriores se publicaron conjuntamente por la edición F.C.U. en un volumen: Los principios generales de Derecho en el Derecho uruguayo y comparado. Segunda edición. Montevideo: 2005; conjuntamente con tres estudios de Daniel H. Martins: "Introducción. Derecho positivo y doctrina nacional posteriores a 1958" y "Reseña de la actual doctrina administrativista iberoamericana".

41 Cajarville Peluffo, J.P. “Invalidez de los actos...”. Ob. cit., pp. 102-109.

42 lbíd., pp. 109-115.

43 Por ejemplo, la ley 15.903 del 10 de noviembre de 1987, artículo 517 (redición ley 16.320 del primero de noviembre de 1992, artículo 400), tocaf, artículo 63, transcrito en una nota anterior, limita las modificaciones cuantitativas de las prestaciones objeto de los contratos. 
cualquier aspecto del contenido del contrato ${ }^{44}$ en tanto los motivos que la justifiquen lo hagan necesario y el logro de la idoneidad del contrato para satisfacer el fin debido lo requiera.

Pero la discrecionalidad de la administración encuentra otro límite, ya que dos aspectos del contrato originario deben considerarse excluidos de la mutabilidad: la esencia del objeto del contrato y las cláusulas de contenido puramente patrimonial, entre ellas por excelencia el precio pactado en el contrato, no pueden modificarse ${ }^{45}$. El contratista tiene un derecho subjetivo, emanado del contrato, a percibir el precio acorda$\mathrm{do}^{46}$, que no puede ser desconocido ni afectado por acto unilateral de la administración sin fundamento legal.

Más ampliamente, la llamada "ecuación económico-financiera" del contrato, como equilibrio de las prestaciones previsto y acordado por las partes en el momento de su celebración, debe ser respetada y, si resultara alterada, deberá restablecerse mediante modificaciones de las obligaciones de las partes que recompongan aquel equilibrio inicialmente consentido ${ }^{47}$.

\section{MODIFICACIONES IMPUESTAS POR EL DERECHO}

Sin perjuicio de esa discrecionalidad de principio, en ciertos casos la modificación del contrato se produce de pleno derecho, con prescindencia

44 García de Enterría, E. y R. Fernández. Curso de Derecho administrativo. Ob. cit., pp. 737-738; Escola, H.J. Tratado integral de los contratos... Ob. cit., p. 399; Dromi, R. Licitación pública. Ob. cit., pp. 506; Marienhoff, M.S. Tratado de Derecho administrativo... Ob. cit., p. 399.

45 Sayagués Laso, E. Tratado... Ob. cit., párrafos 389 y 390, pp. 474-475; Delpiazzo, C.E. Contratación administrativa. Ob. cit., pp. 216 y 222-223. A. Durán Martínez afirma más rígidamente en nuestro Derecho la inmutabilidad de principio del contrato de la administración, salvo ley formal habilitante de la mutación unilateral. En "Ejecución de los contratos...". Ob. cit., pp. 67-75. En la doctrina extranjera, véase Jeze, Gastón. Principios generales del Derecho administrativo, tomo V. Buenos Aires: 1950, p. 191 sobre el contrato de obra pública y pp. 324 y 333-334 sobre el contrato de suministros; De Laubadere, A. et al. Traité de Droit Administratif. Ob. cit., pp. 769-770 y 772773; Rivero, J. Droit Administratif. Ob. cit., pp. 124 y 126; Vedel, G. Droit Administratif. Ob. cit., pp. 252-253 y 255-256; Chapus, R. Droit Administratif Général, tomo 1. Ob. cit., p. 749; García de Enterría, E. y R. Fernández. Curso de Derecho... Ob. cit., pp. 733, 740 y 742-743; Garrido Falla, F. Tratado de Derecho... Ob. cit., p. 91; Parada, R. Derecho administrativo. Ob. cit., pp. 281-282; Santamaría Pastor, J.A. y L. Pareja Alfonso. Derecho administrativo... Ob. cit., pp. 419420; Bandeira de Mello, C.A. Curso de Direito... Ob. cit., pp. 577-579 y 596; Brewer-Carias, A.R. Contratos administrativos. Ob. cit., pp 176-180 y 202-218; Marienhoff, M.S. Tratado de Derecho administrativo. Ob. cit., pp. 399-403, 449, 453 y 475; Cassagne, J.C. La sustantividad del contrato... Ob. cit., pp. 128-129; Dromi, R. Licitación pública. Ob. cit., pp. 505 y 519; Escola, H.J. Tratado integral... Ob. cit., pp. 396-398 y 452-454. Confróntese la sentencia Tribunal de lo Contencioso Administrativo № 964 del primero de septiembre de 1999.

46 Sayagués Laso, E. Tratado..., tomo II. Ob. cit., párrafos 545 y 546, pp. $90-92$ (obra pública); Delpiazzo, C.E. Contratación administrativa. Ob. cit., pp. 220, 287 (obra pública), 330 (suministros); Jeze, G. Principios generales..., tomo V. Ob. cit., pp. 89-92; Chapus, R. Droit Administratif..., tomo 1. Ob. cit., p. 747; Parada, R. Derecho administrativo, tomo I. Ob. cit., pp. 342 (obra pública); Brewer-Carias, A.R. Contratos administrativos. Ob. cit., pp. 186-192; Marienhoff, M.S. Tratado de Derecho... tomo III-A. Ob. cit., pp. 449 y 453, y tomo III-B. Buenos Aires: 1970, pp. 551 (obra pública) y 657 (suministro); Dromi, R. Licitación pública. Ob. cit., pp. 515-518; Escola, H.J. Tratado integral..., volumen I. Ob. cit., pp. 444; Pérez Hualde, Alejandro. Renegociación de contratos públicos. Buenos Aires: 2002, pp. 70-71.

47 Delpiazzo, C.E. "Renegociación de las tarifas...”. Ob. cit., pp. 28-29.

MUTABILIDAD

DELOS

CONTRATOS DE LA

ADMINISTRACIÓN

ENEL

DERECHO

URUGUAYO

MUTABILITY OF

MANAGEMENT

CONTRACTS IN

URUGUAYAN LAW 
de la voluntad de las partes, y en otros deviene en un acto debido para la administración.

En tales casos, la discrecionalidad de la administración puede subsistir en cuanto a la opción entre varios nuevos contenidos, todos ellos idóneos para lograr el fin debido ${ }^{48}$, pero habrá desaparecido en cuanto al hecho en sí mismo de modificar el contrato.

La modificación de pleno derecho ocurrirá cuando una obligación de alguna de las partes se extinga por la ocurrencia de un caso de fuerza mayor insuperable que haga imposible su cumplimiento; en tal caso, si esa obligación no es de las que configuran su sinalagma esencial, el contrato subsistirá pese a esa modificación en su contenido obligacional ${ }^{49}$.

Naturalmente, puede ocurrir que en tal caso no exista acuerdo entre las partes sobre la existencia o la calificación del caso como fuerza mayor insuperable y la consiguiente extinción de la obligación afectada. Entonces, aunque la modificación del contenido obligacional ocurra de pleno derecho, habrá necesidad de un acto declarativo que podrá ser administrativo o, en su defecto, deberá ser jurisdiccional.

Extinguida esa obligación, las partes pueden acordar o la administración puede disponer otras modificaciones del contrato que restablezcan el equilibrio inicial de las recíprocas prestaciones.

La modificación puede ser un acto debido, asimismo, cuando ha sido estipulada en el propio contrato para determinadas circunstancias de hecho. La inestabilidad monetaria y de precios relativos y los procesos de inflación, como fenómenos crónicos de la economía contemporánea, incluso en los países desarrollados, han hecho habitual la existencia de cláusulas de ajuste o de corrección monetaria del precio de los contra$\operatorname{tos}^{50}$ que no afectan el principio de inalterabilidad del precio sino que tienden a mantener su significación económica y, con ello, la equivalencia de sus prestaciones que las partes asumieron al contratar. Estas

\footnotetext{
48 Cajarville Peluffo, J.P. "Invalidez de los actos...". Ob. cit., pp. 107-108.

49 Levrero Bocage, Constancio. "Fuerza mayor, 'sujétions imprévues', 'fait du prince', imprevisión". Revista D.J.A., tomo 57, Montevideo, pp. 120-121 y 126-127; Escola, H.J. Tratado integral... Ob. cit., pp. 430-433; Marienhoff, M.S. Tratado de Derecho..., tomo III-A. Ob. cit., pp. 355-369.

50 Sayagués Laso, E. Tratado..., tomo I. Ob. cit., párrafos 391, p. 476, nota 3, y tomo II, ob. cit., párrafos 546, pp. 91-92 (obra pública); Delpiazzo, C.E. Contratación administrativa. Ob. cit., pp. 330 (suministros); Chapus, R. Droit Administratif..., tomo 1. Ob. cit., p. 747; Garrido Falla, F. Tratado de Derecho..., volumen II. Ob. cit., p. 97-99; García de Enterría, E. y R. Fernández. Curso de Derecho..., volumen I. Ob. cit., pp. 718-720; Parada, R. Derecho administrativo, tomo I. Ob. cit., pp. 345-346; Santamaría Pastor, J.A. y L. Pareja Alfonso. Derecho administrativo... Ob. cit., pp. 441453; Bandeira de Mello, C.A. Curso de Direito... Ob. cit., pp. 571-573 y 589-593; Brewer-Carias, A.R. Contratos administrativos. Ob. cit., pp. 195-199 y "Algunas consideraciones sobre las cláusulas de variación de precios en los contratos administrativos". En Estudios de Derecho administrativo... tomo I. Montevideo: 1979, pp. 55-67; Marienhoff, M.S. Tratado de Derecho..., tomo II-B. Buenos Aires: 1970, pp. 556-563; Gordillo, Agustín A. "Mayores costos, imprevisión, indexación". En Vs. autores, contratos administrativos. regímenes de pago y actualización, tomo I. Buenos Aires: 1968, pp. 103-111.
} 
cláusulas "obligan estrictamente a ambas partes" ${ }^{51}$ e integran el derecho del contratista al mantenimiento del precio acordado ${ }^{52}$.

La modificación deviene un acto debido, impuesto por el Derecho, cuando el contenido del contrato sea probadamente inidóneo para lograr el fin debido de satisfacer las necesidades de interés público a las que está destinado. El deber jurídico de perseguir el fin debido transformará en ilegítimo el comportamiento administrativo que signifique necesariamente incumplimiento de ese deber.

La modificación también puede devenir un acto debido, impuesto por el Derecho, cuando ocurran determinadas circunstancias de hecho imprevisibles al celebrar el contrato que alteren la ecuación económicofinanciera prevista en ese momento por las partes, lo cual torna más onerosa la ejecución del contrato para el contratista. Así ocurre en las hipótesis que hacen aplicables las conocidas como "teoría de la imprevisión", "teoría del hecho del príncipe" y "teoría de las sujeciones imprevistas", según los hechos sean ajenos a ambas partes, imputables a la entidad estatal o consistan en circunstancias materiales preexistentes al contrato pero desconocidas al celebrarlo ${ }^{53}$.

En tales casos, las tres teorías tienen precisamente por finalidad restablecer la ecuación alterada por las circunstancias no previstas mediante la modificación transitoria o definitiva del contenido del contrato ${ }^{54}, \mathrm{o}$, en su defecto, estableciendo a cargo de la administración, si es necesario en vía jurisdiccional, la obligación no prevista contractualmente de compensar al contratista por la mayor onerosidad que debe soportar para cumplir el contrato en las nuevas condiciones, con alcance variable según los casos.

De tal manera, aun en ausencia de estipulaciones contractuales, la llamada "ecuación económico-financiera" del contrato, como equilibrio

51 Sayagués Laso. Tratado..., tomo II. Ob. cit., p. 92. Confróntese Brewer-Carias. Contratos administrativos. Ob. cit., p. 200, y "Algunas consideraciones sobre...”. Ob. cit., p. 60; Marienhoff. Tratado de Derecho..., tomo II-B. Ob. cit., p. 563; Gordillo. "Mayores costos, imprevisión...". Ob. cit., pp. 108-110.

52 Laubadere et al. Traité de Droit Administratif, tomo I. Ob. cit., pp. 773-774; Parada. Derecho administrativo, tomo I. Ob. cit., pp. 345; Bandeira de Mello. Curso de Direito... Ob. cit., p. 592.

53 La bibliografía sobre estos temas es inagotable; si nos limitamos a la nacional, podemos señalar Sayagués Laso. Tratado de Derecho..., tomo I. Ob. cit., párrafos 391, pp. 475-477, y tomo II. Ob. cit., párrafos 512-514, pp. 56-62 y párrafos 548-550, pp. 93-95; Levrero Bocage. "Fuerza mayor...". Ob. cit., p. 121-130; Ruocco, Graciela. "Ejecución de los contratos. Alteración de la ecuación económico financiera del contrato. Teorías del hecho del príncipe, imprevisión y sujeciones imprevistas". En Instituto de Derecho administrativo. Contratación administrativa. Montevideo: FCU, 1989, pp. 77-93; Delpiazzo, C.E. Contratación administrativa. Ob. cit., pp. 222-225.

54 Levrero Bocage. "Fuerza mayor...". Ob. cit., p. 125-126; Delpiazzo. Contratación administrativa. Ob. cit., pp. 217 y "Renegociación de las tarifas...". Ob. cit.; Laubadere et al. Traité de Droit Administratif, tomo I. Ob. cit., p. 784; Chapus. Droit Administratif... Ob. cit., pp. 751-752. Sobre la compensación de la mayor onerosidad mediante modificaciones de tarifas, del precio pactado, subvenciones, cambios del canon o cualquier otra compensación económica, véase Brewer-Carias. Contratos administrativos. Ob. cit. p. 229; García de Enterría y Fernández. Curso de Derecho... Ob. cit., p. 747; Santamaría Pastor y Pareja Alfonso. Derecho administrativo... Ob. cit., p. 436. 
de las prestaciones previsto y acordado por las partes en el momento de su celebración, se tutela en la contratación administrativa con una eficacia que supera la que recibe un acuerdo entre particulares.

La importancia de estas "teorías" en la teoría de la contratación de la administración justifica alguna referencia complementaria, tendiente sobre todo a su recíproco deslinde en el Derecho uruguayo.

\section{LAS "TEORÍAS" SOBRE EL MANTENIMIENTO \\ DE LA ECUACIÓN ECONÓMICO-FINANCIERA DE LOS CONTRATOS DE LA ADMINISTRACIÓN} La jurisprudencia francesa y la doctrina sobre sus pasos han elaborado un conjunto coherente de "teorías" que contemplan diversas circunstancias que pueden alterar la ecuación económico-financiera prevista por las partes al contratar, en un contrato en que sea parte una administración estatal. Su universal aceptación en el Derecho comparado contemporáneo inducen a considerarlas principios generales de la contratación de la administración, integrantes del ordenamiento jurídico uruguayo. Así las expone la doctrina nacional y las recoge la relativamente escasa jurisprudencia de los tribunales estatales y arbitrales.

Las diversas teorías se distinguen por los supuestos de hecho que contemplan cada una de ellas y, determinado cuál es aplicable según esos supuestos, divergen en las consecuencias jurídicas que producen.

\section{VIII.1. Hechos ajenos a las partes}

El mismo tipo de acontecimientos — posteriores a la celebración del contrato, ajenos a las partes, imprevisibles en el caso concreto ${ }^{55}$, irresistibles-que inciden en la ejecución de un contrato son contemplados en materia de contratación administrativa por dos institutos: la "teoría de la fuerza mayor" y la "teoría de la imprevisión".

Ambas teorías, universalmente admitidas, son de recibo en nuestro Derecho; al respecto, la doctrina es unánime.

La teoría de la fuerza mayor es aplicable cuando el acontecimiento provoca la imposibilidad de cumplir con las obligaciones asumidas, transitoria o definitivamente. El efecto de la aplicación de la teoría consiste

55 Sobre la noción de imprevisibilidad a estos efectos, véase Levrero Bocage, C. "Fuerza mayor...". Ob. cit., pp. 129-130. Sobre la huelga como acontecimiento que no puede considerarse razonablemente como imprevisible en la realidad social actual, véase la Sentencia del Tribunal Supremo Español del 3 de junio de 1985, según la exponen Santamaría Pastor y Pareja Alfonso en Derecho administrativo... Ob. cit., p. 466; la Jurisprudencia del Consejo de Estado Francés, ob. cit., en De Laubadere et al. Traité de Droit..., tomo I. Ob. cit., p. 778; Barra, R.C. Contrato de obra pública, tomo 3. Ob. cit., p. 1196. 
en la justificación del incumplimiento del deudor, quien es exonerado de responsabilidad por los daños y perjuicios ocasionados por su falta de cumplimiento y, por ende, es liberado de la obligación de repararlos ${ }^{56}$.

El Derecho privado solo reconoce a tal efecto la imposibilidad absoluta de cumplimiento ${ }^{57}$. En cambio, en el Derecho público se ha abierto camino la denominada "fuerza mayor administrativa", que admite aquellos efectos liberatorios aun en casos de imposibilidad relativa ${ }^{58}$.

Cuando la imposibilidad es transitoria, sus efectos también lo son, de manera que no produce la extinción de las obligaciones cuyo cumplimiento se imposibilita, sino solo la suspensión de su exigibilidad. Si la imposibilidad es definitiva, produce la extinción de la respectiva obligación, y eventualmente de todo el contrato cuando todas las obligaciones de la parte, o al menos aquellas que constituyen la sustancia del sinalagma contractual son las afectadas.

El supuesto de la teoría de la imprevisión consiste en el acaecimiento de circunstancias de hecho, de índole fundamentalmente económica, ajenas a las partes, ocurridas con posterioridad a la contratación, que no pudieron ser previstas en su ocurrencia, en sus consecuencias o aun en su intensidad, que alteran sustancial y transitoriamente el equilibrio de las prestaciones recíprocas previsto y pactado en el contrato, y en consecuencia lo tornan más oneroso para el cocontratante ${ }^{59}$.

En esas situaciones se reconoce a quien ha contratado con la administración el Derecho a que se restablezca en medida variable según los casos aquel equilibrio; se traslada, así, la mayor onerosidad resultante de las circunstancias imprevistas sin que la existencia y exigibilidad de sus obligaciones contractuales se vea afectada. Ello puede lograrse por distintas vías, según el contenido del contrato. La más común consiste en el reconocimiento al cocontratante del derecho a reclamar por parte de la administración una indemnización que cubra total o parcialmente los mayores $\operatorname{costos}^{60}$, o incluso excepcionalmente que restablezca integralmente la ecuación y se incluyan los beneficios previstos ${ }^{61}$.

56 Sayagués Laso. Tratado de Derecho administrativo, tomo II. Ob. cit., párrafos 521, p. 68, párrafos 551 , p. 96 y párrafos 557, p. 98 . El autor admite la rescisión del contrato por fuerza mayor sin responsabilidad para ninguna de las partes como un principio general de Derecho. También, Levrero Bocage. "Fuerza mayor...”. Ob. cit., p. 120-121 y 126-127; Delpiazzo. Contratación administrativa. Ob. cit., p. 250; Cajarville Peluffo. "Extinción de los contratos...". Ob. cit., p. 119.

57 Gamarra, Jorge. Tratado de Derecho civil uruguayo, tomo XVII, volumen 1, Montevideo: 1976, pp. 142-143.

58 Levrero Bocage. Ob. cit., p. 120-121 y 126-127; Cajarville Peluffo. "Extinción de los contratos...". Ob. cit., pp. 117 y siguientes.

59 Sayagués Laso. Tratado... Ob. cit., párrafos 391, pp. 475-477, y tomo II, ob. cit., párrafos 514, pp. 61 y 62, y párrafos 550, p. 95; Levrero Bocage. Ob. cit., pp. 124-126; Delpiazzo. Ob. cit., pp. 224-225; Ruocco. Ob. cit., pp. 84-91.

60 Sayagués Laso. Tratado..., tomo II. Ob. cit., párrafos 514, p. 62; Levrero Bocage. Ob. cit., p. 125.

61 Delpiazzo. Ob. cit., p. 225; Ruocco. Ob. cit., p. 86-87.

MUTABILIDAD

DELOS

CONTRATOS DE LA

ADMINISTRACIÓN

ENEL

DERECHO

URUGUAYO

MUTABILITY OF

MANAGEMENT

CONTRACTS IN

URUGUAYAN LAW 
Pero según la índole del contrato, la contribución de la administración al restablecimiento del equilibrio contractual puede ser de otra naturaleza: por ejemplo, autorizar incrementos en las tarifas, si se trata de la prestación de un servicio público, o de los peajes en una concesión de obra pública ${ }^{62}$. Aunque la alteración de la ecuación económico-financiera del contrato considerada por la teoría es en principio transitoria, si ella adquiere carácter definitivo e irreversible, se reconoce al cocontratante el derecho a obtener una revisión de los términos del contrato que restablezca el equilibrio inicialmente pactado ${ }^{63}$.

El fundamento de esta teoría que han expuesto en general la jurisprudencia y la doctrina donde tuvo su origen es, a primera vista, de orden pragmático: si en las nuevas circunstancias se obligara al cocontratante a cumplir el contrato en los términos pactados, se provocaría en definitiva su ruina y el consiguiente incumplimiento del contrato, y entonces la administración debería celebrar un nuevo contrato con otro tercero en términos que necesariamente contemplarían la situación económica creada por las circunstancias que alteraron la ecuación económicofinanciera del anterior. Es preferible entonces mantener el contrato ya celebrado y contemplar los efectos de esas circunstancias imprevistas, como se haría en el eventual nuevo contrato ${ }^{64}$.

Si se analiza detenidamente esta teoría, se percibe que existen fundamentos de orden jurídico muy profundos, además de aquella razón pragmática. Por supuesto, milita en favor de la solución patrocinada por esta teoría el principio fundamental de equidad, así como el de ejecución de buena fe de los contratos. Además, si se tiene en cuenta que a diferencia de los particulares la administración debe actuar siempre y solo puede actuar persiguiendo como fin el interés general, se percibirá que el principio de igualdad, base de nuestro ordenamiento jurídico, en su especificación de "igualdad ante las cargas públicas", impone las soluciones que patrocina esta teoría ${ }^{65}$. No es adecuado a este principio que, para satisfacer el interés general que la administración persiguió al contratar, se obligue a un particular a sacrificarse hasta la ruina para cumplir lo pactado. La entidad estatal a la que se ha confiado la satisfacción de aquel interés general en pos del cual contrató o, en su caso, los beneficiarios directos e individualizados del servicio o de la obra deben contribuir equitativamente al logro de aquella satisfacción.

62 Sayagués Laso. Tratado..., tomo II. Ob. cit., párrafos 512, p. 57 y párrafos 514, p. 62.

63 Levrero Bocage. Ob. cit., p. 125-126; Delpiazzo. "Renegociación de las tarifas...”. Ob. cit.

64 Es el fundamento que recogen Sayagués Laso. Tratado..., tomo II. Ob. cit., párrafos 514, p. 61; y Levrero Bocage. Ob. cit., p. 124.

65 Delpiazzo. Ob. cit., p. 225. También se ha fundamentado la teoría en la necesidad de asegurar el buen funcionamiento del servicio, por ende en razones de interés general y en la tutela y garantía plena del derecho de propiedad del cocontratante. Véase Ruocco. Ob. cit., p. 87-91. 
Esta teoría se aplica aun a falta de regulación alguna en el contrato, como principio general de la contratación administrativa ${ }^{66}$, universalmente admitido por la doctrina y la jurisprudencia, así como por nuestra práctica administrativa.

Las características similares de los acontecimientos —ajenos a las partes, imprevisibles, irresistibles_ que condicionan la aplicación de ambas teorías plantea la cuestión de su eventual acumulación ante un mismo evento.

Esa acumulación no es posible en todas las hipótesis en que se trate de un acontecimiento que provoque la imposibilidad definitiva de cumplimiento, absoluta o relativa. En tal caso, si la imposibilidad recae sobre la sustancia contractual, el contrato se extingue sin responsabilidad para el contratante incumplidor, y no cabe aplicar la "teoría de la imprevisión", que presupone la supervivencia del contrato.

Pero cuando el acontecimiento en cuestión provoca solamente una imposibilidad transitoria de ejecución, la acumulación de ambos institutos y de sus respectivos efectos se impone. El deudor no será responsable de los daños y perjuicios que produzca al otro contratante la demora en la ejecución ocurrida por fuerza mayor y no deberá por ende repararlos; y, dado el carácter transitorio de la imposibilidad de cumplimiento, las obligaciones y el contrato mismo subsisten, sin perjuicio de la suspensión de su exigibilidad. Si además el acontecimiento en cuestión provoca una alteración sustancial y transitoria de la ecuación económico-financiera del contrato en perjuicio del cocontratante, la aplicación de la "teoría de la imprevisión" obligará a reconocerle el derecho a una compensación debida por la administración.

Aun cuando en una determinada circunstancia de hecho corresponda la aplicación acumulativa de ambas teorías, sus respectivos ámbitos conceptuales permanecen nítidamente diferentes. La "teoría de la imprevisión" noatañe ala reparación de los daños causadosa un contratante (acreedor de la obligación incumplida) por un incumplimiento transitorio del otro contratante ocasionado por un evento de fuerza mayor, sino a la reparación debida a ese otro contratante, deudor de la obligación que no se pudo cumplir, en razón de la mayor onerosidad que causará aquella postergación del cumplimiento provocada por el evento de fuerza mayor.

66 La doctrina nacional es incluso más terminante, pues sostiene que "las cláusulas convencionales no pueden prever todas las situaciones que en los hechos pueden tener lugar y que la existencia de las mismas [sic] no constituye obstáculo suficiente para la aplicación de las soluciones de la teoría de la imprevisión". Levrero Bocage. Ob. cit., p. 130. Confróntese el Tribunal de lo Contencioso Administrativo, sentencia № 160 de 28-4-986, en el Anuario de Derecho administrativo, tomo I, № 118 , Montevideo, 1987, p. 27.

MUTABILIDAD

DELOS

CONTRATOS DE LA

ADMINISTRACIÓN

ENEL

DERECHO

URUGUAYO

MUTABILITY OF

MANAGEMENT

CONTRACTS IN

URUGUAYAN LAW 


\section{VIII.2. Circunstancias materiales preexistentes}

Durante la ejecución de un contrato pueden conocerse circunstancias materiales anormales relativas al objeto de las obligaciones del contratante o a los bienes sobre los que deban ejecutarse, que preexistían a su celebración ${ }^{67}$, pero no fueron conocidas ni previstas y eran razonablemente imprevisibles para las partes al momento de contratar. Estas circunstancias materiales no hacen imposible el cumplimiento, pero inciden en la ecuación económico-financiera y la tornan más onerosa para el contratante. Por las características del evento, su posibilidad se señala generalmente en relación con los contratos que implican la ejecución de una obra pública, aunque teóricamente puede concebirse su acaecimiento en contratos con otro objeto.

Estas circunstancias no eximen al contratante de cumplir con las obligaciones asumidas, pero generan en su favor el derecho a ser íntegramente indemnizado, tanto del daño emergente como del lucro cesante. En su originaria denominación francesa, se trata de la conocida teoría de las sujétions imprévues o "teoría de las sujeciones u obligaciones imprevistas" ${ }^{8}$.

Si las dificultades imprevistas de ejecución del contrato provocan una alteración radical en la ecuación contractual, el derecho a la compensación integral en favor del contratante surge aun cuando el contrato hubiera previsto un precio global predeterminado por obras también globalmente previstas, o cuando por otra vía se hubiera previsto la exclusión de mayor precio por mayores costos, por cuanto se considera que esas previsiones contractuales cubren las dificultades normales y por ello razonablemente previsibles de ejecución de las obligaciones contractuales, pero no las desconocidas por las partes y razonablemente imprevisibles ${ }^{69}$.

\section{VIII.3. Hechos o actos imputables a la administración}

Finalmente, la ecuación económico-financiera del contrato puede verse también alterada durante su ejecución por una actuación —acto o hecho- de la administración contratante ${ }^{70}$, arreglada a Derecho ${ }^{71}$, cumplida espontáneamente ${ }^{72}$ en ejercicio de sus potestades públicas y no

67 Ruocco. Ob. cit., pp. 91-92.

68 Sayagués Laso. Tratado..., tomo II. Ob. cit., párrafos 548 y 549, pp. 93-95; Levrero Bocage. Ob. cit., p. 121-122 y 127-128; Ruocco. Ob. cit., pp. 91-92; Delpiazzo. Ob. cit., pp. 225-226.

69 Levrero Bocage. Ob. cit., pp. 121-122.

70 Si fuese una actuación de otra administración, podría tratarse de una hipótesis de aplicación de la "teoría de la imprevisión" o incluso de responsabilidad extracontractual de esa otra administración, según el caso. Levrero Bocage. Ob. cit., p. 122 y 128-129; Ruocco. Ob. cit., p. 81-82. En contra está Sayagués Laso. Tratado..., tomo II. Ob. cit., párrafos 513 , p. 60 . El autor sostiene que es indiferente que el acto emane de la persona pública concedente o de otra persona pública distinta.

71 Si la actuación de la administración fuera ilegítima, se trataría de una hipótesis de responsabilidad por ilegitimidad, contractual o extracontractual, según el caso. Véase Levrero Bocage. Ob. cit., p. 122, y Ruocco. Ob. cit., p. 80.

72 En el sentido de no provocada o requerida por el cocontratante ni por circunstancias extraordinarias ajenas a las partes, hipótesis esta última encartable en la "teoría de la imprevisión". Levrero Bocage. Ob. cit., p. 122; Delpiazzo. Ob. cit., p. 224; Ruocco. Ob. cit., p. 80. 
de facultades contractuales ${ }^{73}$, por ende necesariamente unilateral ${ }^{74}$, subjetiva o general ${ }^{75}$, imprevista al contratar ${ }^{76}$, que hace más onerosa la ejecución del contrato causando con ello un perjuicio particular o especial al contratante ${ }^{77}$. Estos acontecimientos dan lugar a la aplicación de la teoría llamada "hecho del príncipe" o "hecho de la administración"78.

También esta circunstancia genera un derecho a la indemnización integral - daño emergente y lucro cesante- en favor del cocontratante ${ }^{79}$, que en nada ve atenuadas la existencia y exigibilidad de sus obligaciones contractuales $^{80}$. Pero también en este caso, según la índole del contrato, el restablecimiento del equilibrio contractual puede ser de otra naturaleza, por ejemplo mediante incrementos en las tarifas, si se trata de la prestación de un servicio público, o de los peajes en una concesión de obra pública ${ }^{81}$.

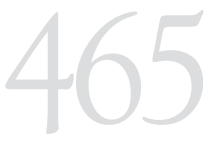

MUTABILIDAD

DELOS

CONTRATOS DELA

ADMINISTRACIÓN

ENEL

DERECHO

URUGUAYO

MUTABILITY OF

MANAGEMENT

CONTRACTS IN

URUGUAYAN LAW

\section{ADMISIÓN DE LA MUTABILIDAD DE LOS CONTRATOS DE LA ADMINISTRACIÓN POR EL TRIBUNAL DE CUENTAS DE LA REPÚBLICA}

Antes se señaló la posición singularmente rígida adoptada por el Tribunal de Cuentas de la República sobre el "principio de inmutabilidad" de los contratos celebrados por la administración. Se aludió allí al caso sin duda más notorio en que el tribunal cuestionó, el 3 de diciembre de 2003, la legitimidad de las modificaciones acordadas por las partes a una concesión de uso de un hotel municipal.

En virtud de una solicitud de reconsideración formulada por la autoridad municipal, con agregación de nuevos antecedentes, el 13 de julio

73 Durán Martínez. “Ejecución de los contratos...”. Ob. cit., pp. 65-66; Ruocco. Ob. cit., pp. 79-80. Si se actuara ejerciendo facultades contractuales, la hipótesis se regiría por los principios del cumplimiento de los contratos.

74 Sobre la unilateralidad del acto de la administración motivante de la alteración perjudicial para el contratista, la doctrina y la jurisprudencia nacional y comparada son unánimes y terminantes. En cuanto a la doctrina y jurisprudencia nacionales, véase la unánime citada en la nota siguiente. En cuanto a la extranjera más reciente, cabe citar a Chapus, R. Droit Administratif..., tomo 1. Ob. cit., pp. 748-750, y De Laubadere et al. Traité de Droit Administratif, tomo I. Ob. cit., pp. 778-780.

75 Sayagués Laso. Tratado..., tomo II. Ob. cit., párrafos 513, p. 59; Levrero Bocage. Ob. cit., p. 122-123, formulando salvedades; Delpiazzo. Ob. cit., p. 224; Ruocco. Ob. cit., p. 82 . El Tribunal de lo Contencioso Administrativo recibe la teoría del factum principis, pero la limita a las medidas administrativas imprevisibles y generales, objetivas: sentencias № 807 del 15 de octubre de 1997 y № 8-98 del 4 de febrero de 1998; sentencia № 3, del primero de febrero de 2001, todas en Anuario de Derecho Administrativo, tomo X, № 190, Montevideo, 2003.

76 Levrero Bocage. Ob. cit., p. 122; Delpiazzo. Ob. cit., p. 224; Ruocco. Ob. cit., p. 80.

77 Levrero Bocage. Ob. cit., p. 122; Ruocco. Ob. cit., p. 80.

78 Sayagués Laso. Tratado..., tomo II. Ob. cit., párrafos 512 y 513, pp. 56-61, y párrafos 548 y 549, pp. 93-95; Levrero Bocage. Ob. cit., pp. 122-124 y 128-129; Ruocco. Ob. cit., pp. 79-84; Delpiazzo. Ob. cit., p. 224.

79 Sayagués Laso. Tratado..., tomo II. Ob. cit., párrafos 513, p. 60; Levrero Bocage. Ob. cit., p. 123; Delpiazzo. Ob. cit., p. 224.

80 Sin embargo, Levrero Bocage (ob. cit., p. 124) admite que, en ciertos casos, el hecho de la administración puede justificar el incumplimiento del contratista.

81 Sayagués Laso. Tratado..., tomo II. Ob. cit., párrafos 513, pp. 60-61; Delpiazzo. "Renegociación de las tarifas...". Ob. cit. 
de 2004 el Tribunal de Cuentas volvió a considerar las modificaciones contractuales propuestas y revisó aquella resolución del 3 de diciembre de 2003 con fundamentos trascendentes.

Después de ratificar que a su criterio "el principio general respecto a la modificación de los contratos administrativos lo constituye la inmutabilidad de los mismos, en mérito a lo previsto en diversas normas de nuestro derecho positivo privado (Artículo 1291 CC)" (considerando 3), reiteró que ese principio "admite excepciones, con las características enunciadas por la doctrina publicista, entre las que se ubica la teoría de la imprevisión, el 'hecho del príncipe' y las sujeciones imprevistas, no obstante carecer nuestro derecho administrativo de normas expresas que regulen dichas excepciones" (considerando 4).

Pero después agregó ${ }^{82}$ :

[...] que corresponde a la voluntad de las partes y fundamentalmente a la iniciativa del cocontratante invocar la existencia de hechos, que afectan la ecuación económico-financiera tenida en cuenta al celebrar el contrato, entablando negociaciones tendientes a preservarlo por razones de interés público que apunten a un nuevo equilibrio económico entre ellas (considerando 5);

[...] que en ese sentido la moderna doctrina del derecho público establece que "cuando las condiciones pactadas no cubren las alternativas en que se produce la ejecución del contrato y sus previsiones se tornan ineficaces por alguna causa, se impone el replanteo de las mismas para obtener el objetivo de satisfacción del bien común al que apuntaron las partes al contratar" (considerando 6);

[...] que el Tribunal en su resolución del 3.12.03 expresó que entre las causas que podrían dar lugar a una revisión del contrato se ubica la citada teoría de imprevisión, para cuya aplicación deben configurarse determinados supuestos, entre los cuales algunos requieren una evaluación subjetiva de las partes y otros tienen carácter objetivo como lo es el caso de la transitoriedad de la situación. No obstante el carácter objetivo de este supuesto como bien se ha sostenido "cierto es que en muchos casos la situación imprevista se consolida definitivamente y desaparece toda posibilidad de retorno a las condiciones primitivas existentes al momento de formalizarse la convención. En esta hipótesis, la solución (que en la práctica se ha dado solamente en el caso de las concesiones, contrato que por su larga duración es afectado más profundamente por la permanencia del desequilibrio económico) se logra por medio de una modificación de las cláusulas del contrato" (considerando 7). 
Concluyó sobre este punto lo siguiente: "En consecuencia es privativo de la voluntad de las partes iniciar negociaciones ante un acto o hecho perturbador generador de la alteración que se produce en la ecuación económico-financiera del contrato, acreditada la cual el Cuerpo analizará la legitimidad de las modificaciones" (considerando 14).

En cuanto al principio de igualdad de los oferentes en la licitación, sobre el cual tanto hincapié había hecho en su resolución del 3 de diciembre de 2003, dijo ahora el tribunal:

No resulta afectado en modo alguno el principio de igualdad, si se modifica el contrato en función de los hechos y fundamentos acreditados en este caso mediante la nueva documentación aportada. En efecto, en nada se perjudican otros eventuales proponentes, ya que de haber existido y de haber ganado la licitación, también habrían tenido la posibilidad ante iguales circunstancias de entablar negociaciones y de acordar modificaciones como lo efectuó el adjudicatario de esta licitación (considerando 13).

Muy lejos están estos conceptos del tribunal de la rígida aplicación de la inmutabilidad de los contratos, contenida en sus resoluciones del 3 de diciembre de 2003 y del 20 de mayo de 2004. Es claro que el reconocimiento de la legitimidad de la negociación entre las partes para modificar el contenido del contrato, cuando se ha producido una alteración en su ecuación económico-financiera o cuando sus estipulaciones han devenido ineficaces para la satisfacción del interés público, unido esto a su explícita aceptación de las "teorías" sobre el mantenimiento de la ecuación económico-financiera del contrato alterada por circunstancias supervinientes, han llevado a identificar la posición del tribunal con la sostenida por la doctrina administrativista nacional y comparada sobre el tema. Todo ello ocurre sin perjuicio de su reiterada afirmación del "principio de inmutabilidad de los contratos de la administración" que funda en "normas de nuestro derecho positivo privado".

\section{CONCLUSIÓN}

A semejanza de la solución vigente en el Derecho comparado, también en el Derecho positivo uruguayo debe admitirse, aun en ausencia de norma expresa, la mutabilidad de los contratos celebrados por la administración cuando sus estipulaciones obsten al debido cumplimiento de sus cometidos conforme con el Derecho y los principios de buena administración y en virtud de circunstancias supervinientes a la celebración del contrato o, en su caso, a la presentación de las ofertas en el procedimiento competitivo previo, con la finalidad de posibilitar la satisfacción del interés público perseguido al contratar. 
Pero de ninguna manera la admisión de tal solución como un principio propio de la contratación de la administración puede justificar la modificación de un contrato cuya ecuación económico-financiera haya sido inviable $a b$ initio, como consecuencia de errores del cocontratante en que haya incurrido por su propia culpa o, como suele ocurrir, de la presentación de ofertas formuladas de mala fe con el único propósito de triunfar en el procedimiento competitivo y con la premeditada intención de pretender su modificación favorable durante la ejecución de contrato. En tal caso, solo será lícito a la administración exigir el cumplimiento en los términos pactados y aplicar todas las sanciones y reclamar la reparación de todos los daños y perjuicios causados, si el cocontratante no cumpliera con sus obligaciones tal como fueron asumidas.

Si en tales oportunidades la administración admitiera la modificación del contrato, su decisión sería ilegítima porque las circunstancias de hecho o los motivos de su actuación no conducirían razonablemente a esa solución e incurriría en desviación de poder por utilizar su potestad modificatoria con una finalidad que no es la debida. 